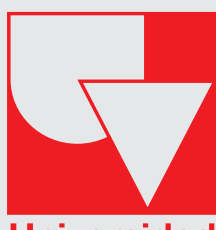

Universidad del Valle

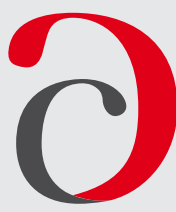

Cuadernos de Administración
Journal of Management

Print ISSN: 0120-4645 / E-ISSN: 2256-5078 / Short name: cuad.adm.

Pages: 148-160 / Vol: 36 / Issue: 66 / Jan. - Apr. 2020

Faculty of Administration Sciences / Universidad del Valle /

Cali - Colombia

\title{
Reflections on Responsible Tourism in the Framework of Social Responsibility
}

\author{
Reflexiones hacia el Turismo Responsable en el Marco de la Responsabilidad Social
}

\author{
${ }^{1}$ Camilo Mejía Reátiga(D) \\ Director of Center for Innovation and Sustainable Development of Greater Caribbean, Business School \\ Universidad del Norte, Barranquilla, Colombia. e-mail: cmejia@uninorte.edu.co \\ 2 Meylin Ortíz Torres (D) \\ Full Time Teacher, Universidad Sergio Arboleda, Barranquilla, Colombia. e-mail: meylin.ortiz01@usa.edu.co
}

Reflection Article Submitted: $26 / 11 / 2018$ Reviewed: 28/03/2019

Accepted: 30/07/2019

Thematic lines: Administration and Organizations JEL classification: M140-Z320 DOI: https://doi.org/10.25100/cdea.v36i66.7196

\begin{abstract}
This reflection article presents a tour of the fundamental elements of Corporate Social Responsibility (CSR) in the context of the hotel subsector, with special emphasis on sustainability perspectives, known as triple accountability: environmental, social and economic variable. It is expected that the reader can understand from the documentary analysis of the corresponding literature, the relationship between CSR and hotel activity, as well as the relevant variables in the development of responsible practices (as regards triple accountability) of mentioned industry. In addition, this article includes an approach to the opportunities for improvement around these corporate social responsibility practices in the hotel subsector and the gap, praxeology, present between sustainable tourism (as a framework within which the hotel subsector is located) and the responsible tourism, horizon towards which the duty of the subsector is framed.
\end{abstract}

Keywords: Corporate social responsibility, Hotel industry, Sustainability, Certifications, Triple accountability.

\section{Resumen}

El presente artículo de reflexión presenta un recorrido por los elementos fundamentales de la Responsabilidad Social Empresarial (RSE) en el contexto del subsector hotelero, haciendo especial énfasis en las perspectivas de la sostenibilidad, conocidas como triple rendición de cuentas: variable ambiental, social y económica. Se espera que el lector pueda entender, a partir del análisis documental de la literatura correspondiente, la relación entre RSE y la actividad hotelera, así como las variables relevantes en el desarrollo de las prácticas responsables (en lo que a la triple rendición de cuentas respecta) de dicha industria. También se hace una aproximación a las oportunidades de mejora en torno a dichas prácticas de responsabilidad social empresarial en el subsector hotelero y la brecha, praxeologica, presente entre el turismo sostenible (como marco de actuación dentro del cual se encuentra el subsector hotelero) y el turismo responsable, horizonte hacia el cuál se enmarca el deber ser del subsector.

1 Business Administrator, Universidad del Norte, Colombia, Doctor of Administration, Universidad EAFIT, Colombia.

2 Lawyer, Universidad del Norte, Colombia, Magíster, Universidad del Norte, Colombia. 
Palabras clave: Responsabilidad social empresarial, Industria hotelera, Sostenibilidad, Certificaciones, Triple rendición de cuentas.

\section{Introduction}

One of the strong sources of the economy in the world is tourism in its different modalities, according to data from the World Tourism Organization (UNWTO) (2014), tourism activity worldwide contributes $10 \%$ of GDP, $6 \%$ of international trade, $30 \%$ of service exports and provides one in 11 job positions. Colombia is characterized by being one of the countries in which tourism has become an economic source thanks to its social and cultural history, the biodiversity it has and the convenience of its geographical position, which allows it to offer innumerable tourist alternatives both in cities as in rural areas and even in their natural parks.

In this article a documentary analysis is carried out on the relations of social responsibility and the hotel industry. In the first instance, the existing connections between the two are reviewed, later the analysis of the categories implicit in the sustainability of the hotels (economic, social and environmental) is developed and subsequently an initial approach is made to what is understood as responsible tourism, emphasizing the CSR international practices and standards applicable to the hotel industry.

\section{Corporate Social Responsibility in the hotel sector}

Corporate Social Responsibility (CSR) is a concept that is still growing in the tourism sector, and particularly in the hotel sub-sector (Carroll, 1999; FloresRuiz, Bino-Raya, Barroso-González, 2016 p.130; González-Morales, Alvarez- González, Sanfiel-Fumero and Armas-cruz, 2016, p. 563). CSR initiatives in the hotel industry are growing, among which are: social related marketing, corporate philanthropy, green marketing and minority support programs (Kim, Kim, Mattila, 2016). They stand out as "stakeholders" in the hotel sector: the local population, employees belonging to minorities, different local administrations and private companies, among others (Bigné,
Font, and Andreu, 2000; Ejarque, 2005; Martos and Pulido, 2011, Valls, 2004; Martos Molina, 2011).

CSR helps to improve the sustainability of the tourism industry and its customers (Gao and Mattila, 2014), as well as studies reveal that CSR affects customer loyalty (Martínez and del Bosque, 2013). It means that the highest levels of CSR initiatives affect the attitude of consumers towards the company and customer satisfaction (Assaf Josiassen, Jin Sun Ahn, Mattila, 2017, p. 2). However, there is still a high degree of uncertainty and complexity, since there is no certainty if this really affects the criteria of customer choice.

\section{Sustainable development in the CSR of the hotel sector}

Corporate Social Responsibility in the hotel sector has traditionally been defined based on the theory of sustainable development, which some authors consider as the most appropriate approach for the study of CSR in this context (Martínez and Del Bosque, 2013). That is, that CSR is understood from the economic, social and environmental functions of companies. "This means that, instead of being solely responsible for the optimization of profits, companies that engage in CSR should be responsible for their actions with respect to the environment, society and the economy" (Dimitrova and Li, 2016, p. 19).

On the other hand, Corporate Social Responsibility has become a tool for creating value for interest groups, so much so that, "CSR has become a strategy that allows greater market positioning, given that customers and the community in general, feels more identified with those organizations that are committed to the environment and society "(Raufflet, 2012). This is how companies should be able to ensure their long-term economic performance by avoiding short-term behavior, because it is socially and environmentally harmful (Porter and Kramer, 2006).

According to the report of the Portafolio magazine called "Social Responsibility in the Colombian hotel sector" (Torres and Carlier, 2013) and with the study carried out by 'CSR in Tourism Study', in 10 of the most 
prestigious chains in the world, the highest percentage of its actions in CSR (35\%) are aimed at environmental issues. This includes conservation of ecosystems (29\%), uses of new technologies for energy saving (21\%), water (11\%) and recycling (16\%). The $28 \%$ corresponds to social impact actions and the remaining percentage is dedicated to issues such as economic impact and others.

\subsection{Environmental dimension}

The environmental dimension is configured in the interaction and interdependence of the human being with the ecosystem, and will be understood as the eco-systemic possibilities to generate environmental goods and services while the cultural responsibility will be focused to protect the environment. Its mission will be to guarantee the environmental sustainability of development (Vega Mora, 2013).

However, the environmental aspect can be classified into two levels: reactive and proactive (Vo, Delchet-Coche, and Akeb, 2015). The proactive level refers to innovation, eco-efficiency, pollution prevention and environmental leadership in order to minimize the ecological impact on the environment through the adoption of environmental management systems that seek to transform the development of operational activities getting involved, beyond the regulatory plans. On the contrary, the reactive level is defined as concerns to protect the environment by complying only with regulatory norms and standards, that is, those companies that aim to spend only the minimum level of effort required for regulatory compliance (Torugsa, O'Donohue, and Hecker, 2013).

In hotel chains, CSR is acquiring greater consideration in recent years. This is demonstrated by the presentation of sustainability reports, the application of codes of conduct, the development of responsible practices, and quality certifications. Nevertheless, it is insisted that the environmental dimension of CSR has an important weight, limiting the social dimension to the intervention in social programs (Vaca 2013). That is, that CSR in hotel chains is developed to a greater extent from the environmental dimension (Abello, Sendra Vellvé, 2007; Flores-Ruiz et al., 2016; Peña, Guevara, and Fraiz, 2016).

From a macro perspective, the environmental movement in the hotel industry plays an important role in the tourism market, since the environmental protection of hotels allows a significant impact on society (Kang and Atkinson, 2016). In 2014, Trip Advisor conducted a survey that showed results confirming this environmental revolution from the perspective of customers: $23 \%$ of respondents have consciously made an environmentally friendly travel option in the last year, and $85 \%$ said that doing so, made them feel more positive about their trip (Yixiu and Tun.Min, 2017).

As for the scientific literature of CSR and its relationship with the hotel sector, it is found that most of them focus on aspects related to ecotourism, or the ecological impact of tourism and hotel activity. These studies broadly justify the relationship between hotel accommodation activity and the environment. It is shown that those responsible for the establishments perceive the importance of managing the impact they produce on the environment. However, it was evidenced that this happens due to social pressure, the commitment being a minor marketing factor, requiring real knowledge of the impact of establishments on the environment, especially in the case of urban hotels (Bohdanowicz and Zientara, 2008); Fernández and Cuadrado, 2011).

Most of the actions that correspond to the environmental dimension focus on the concepts of sustainability and CSR (FloresRuiz et al., 2016). However, the hotel industry often receives criticism due to its negative influence on local communities because of high water and energy consumption, excessive waste and pollution (Kim et al., 2016). Some hotel chains are already betting reliably on the challenge of sustainability in their hotels and complexes. Numerous references and data on environmental impact reductions and, in turn, reductions in operating costs are given in the reports (Carbó, 2013). According to this author, some of the sustainable practices to reduce the use of the following factors (Table 1). 


\begin{tabular}{|c|c|c|}
\hline \multicolumn{2}{|c|}{ Table 1. Sustainable practices } \\
\hline Energy & Water & Wastes \\
\hline $\begin{array}{c}\text { Exe of renewable energy } \\
\text { Exche of traditional bulbs for LED } \\
\text { type }\end{array}$ & $\begin{array}{c}\text { Use of plumbing that guarantees } \\
\text { reduction of water consumption } \\
\text { Instruments that regulate water } \\
\text { pressure }\end{array}$ & $\begin{array}{c}\text { Reduce hotel waste } \\
\text { Reuse objects, giving them new uses } \\
\text { Recycle }\end{array}$ \\
\hline \multicolumn{2}{|c|}{$\begin{array}{c}\text { Pipe and faucet maintenance } \\
\text { Source: Own elaboration based on Carbó (2013). }\end{array}$} \\
\hline
\end{tabular}

Another of the outstanding measures in reducing environmentalimpactissensitization. Increasingly, hotel accommodations indicate and promote the sustainable measures that can be taken in their establishments. In addition, staff templates take training and environmental awareness courses, which have an impact both on their own actions and on the orientation and assistance to tourists (Carbó, 2013).

It is also accepted that becoming "green" not only meets the needs of customers concerned with the environment and assumes responsibility for the tasks, but also results in substantial cost savings through various environmental benefits" (Carbó, 2013, p. 46).

Responsible practices with the environment merit the collaboration of all parties involved, both employees and hotel guests must understand the reasons for taking care of the environment.

\subsection{Social dimension}

The hotel sector becomes a dynamic axis among cultural issues, which is why it is considered that cultural practices should constitute a dimension with their own identity in the study of CSR (Pérez y Rodriguez Del Bosque, 2015; Bohdanowicz and Zientara, 2008). According to Kirk (1995), hotels can influence on ecology or in local communities (Castillo, 2016), due to their location around important natural, cultural and heritage spaces, However, it seems to be a reality that the impact generated in the local community or directly on its employees does not enjoy greater attention in the hotel sector (Fernández and Cuadrado, 2011).

However, Kirk (1995) states that responsible social behavior can give a hotel firm a commercial advantage with a positive effect on its presentation. In addition, Kabir (2011) states that the image of the hotel is strategic and can help survive competitive conditions, while (García-Rodríguez and Armas-Cruz, 2007) point out that this relationship depends on the local context (Melo, Moura-Leite, and Padgett, 2012)

On the other hand, the social role has the workplace and the community as two focus points in the creation of social cohesion and equity, where aspects such as health, safety and general welfare of employees are recognized through the offer of training and development opportunities, social advances in the community, among others (Vo, DelchetCoche, and Akeb, 2015). According to Porter and Kramer (2006), companies can influence various social factors, such as the local education system, the adequacy of the public health system, availability of accommodation, discrimination, etc. These factors affect the ability of the company to hire and retain adequate human resources.

For hotels, involvement and communication has been one of the key pillars in the new advances of CSR. This is demonstrated by a study called "corporate social responsibility of the five-star hotels in the historic center: a way to contribute to the sustainability of the tourist destination of Cartagena de Indias" and published by The Technological Institution Colegio Mayor de Bolívar, where they affirm that both the neighboring communities and interest groups (stakeholders), employees and clients of the sector consider that conditions such as: higher employment with better pay, better treatment of employees, contributions to community development, creation of foundations and donations to education are the perfect opportunities for that hotels increase their CSR rates (Ocampo, 2015). 
Among the results of this research, it is observed that about $72 \%$ of the surrounding communities and interest groups (partners, and allied companies) affirm that the five-star hotels in the city of Cartagena do implement CSR strategies where it is included the local community. In the same way, it is important that from the executive or directive side it is demonstrated how important the employees are for the organization, listening to them, recognizing their work, and making them feel useful are supremely important actions, since in this way they will feel more comfortable in their jobs, emotions that are transmitted to customers. For this, it is important that customers also perceive the company's commitment. To do this, the hotel must maintain active communication channels, if so "It can thus be perceived as a sustainable hotel, for example, and transmit social values that the guest considers important when deciding where to stay. If this communication is constant and coherent, the hotel chain or the hotel can transmit seriousness and commitment to the environment" (Jaume, 2015).

This is corroborated in the same study, indicating that about $56 \%$ of stakeholders considers that giving better treatment to workers, more employment, better salary and helping the community, are practices that make a hotel more socially responsible, Likewise, $85 \%$ of clients and $73 \%$ of employees consider that community support and quality of work life are key factors within CSR (Ocampo, 2015).

On the other hand, one of the CSR practices in the social role refers to the inclusion of codes of conduct in addition to the development of policies and mechanisms that allow monitoring these codes, an example of this is the integration of CSR into the code of conduct against sexual exploitation (ESC) in the hotel sector. For the above, there is a certification called "The Code" which is the only international certification of corporate social responsibility in the area of sexual exploitation.

\subsection{Economic Dimension}

The hotel industry is a sector capable of generating great profits. In Colombia this industry has stimulated the economy being the result of the incorporation of Corporate Sustainability and CSR in the strategy of companies in the maturity stage. The DANE1 revealed that "Hotel investments have marked the sector, which has become one of the new engines, if we consider that the number of visitors between December 2015 and 2016, in Colombia, had a variation of 9 \%. Last year (2016), 2.6 million people entered, according to figures from Migración Colombia (Romo Mendoza, 2017).

The economic motive has been considered as an important driver of the integration of CSR in business strategy. It can be defined as "the concern about the economic viability of the company, which is reflected in the way a company operates in the market, goes beyond the problems of maximizing shortterm benefits to emphasize the problems of economic performance to long term and effectively exploit market opportunities "(Vo et al., 2015, p. 2).

In the hotel industry, when talking about the economic role, we talk about obtaining alliances in order to generate common benefits. This is how a hotel that previously had "all-inclusive" plans (Room, food, national drinks, tips, entertainment, taxes), today offers plans with complementary attractions (restaurants, visits to tourist sites, beach trips, among others).

According to Jiménez Martínez in his article called "The hotel chains in the world and the evolution of its operation in Mexico at the beginning of the $21^{\text {st }}$ century (2008)", international hotel chains are a product of the conditions of the economy and the expansion policy of companies in the framework of a world in growing interaction that began after the Second World War (Jiménez Martínez, 2008). Therefore, corporate social responsibility is presented as a fundamental tool in the sustainability of hotels, given the relationship of their economic activity with the different interest groups and the culture of the place. As evidenced in the case studies of hotel groups: $\mathrm{NH}$ Hoteles and Sol Melia (Del Río, Cardona, and Pérez, 2012), where their economic activities are guided by an excellent relationship with their employees and customers, in combination with their interest in the conservation of the 
environment of the sectors where they work, which could be the key to their success.

In Colombia, Ministry of Commerce, Industry and Tourism, seeks through sustainable techniques, regulate and provide guidelines so that the different tourism service providers can offer services that have a factor of environmental, economic and cultural sustainability. The ministry seeks that tourism service providers and in this case, hotel chains, implement sustainability policies that, according to the definition set forth in their NTS-TS 202 standard, are the "statements made by the establishment of accommodation and lodging, of its intentions and principles, in relation to its performance in environmental, sociocultural and economic aspects, it provides the framework for action and for the establishment of its objectives and goals "(Ministerio de Comercio, Industria y Turismo, 2014).

For his part, Fernández (2009) argues that the great influence of interest groups in organizations should not be ignored, since from them some problems or opportunities for the growth of hotels could be triggered.

In a descriptive investigation on the development of entrepreneurial activities with innovation and social responsibility in the hotels of the city of Cartagena, the opinion of the workers of some hotels was known, which reflected a degree of nonconformity in the level of innovation of the hotels where they worked respectively, since despite recognizing the efforts of companies to create a differentiating factor, they did not find the most suitable method in all situations (Molina, 2011). Likewise, in the aforementioned research, a relationship was discovered between the company's fear of failure and the understanding of concepts such as innovation and social responsibility; employees who know about continuous innovation did not express fear of failure, unlike those who do not know about CSR and innovation (Molina, 2011).

Likewise, in the afore mentioned research, a relationship was discovered between the company's fear of failure and the understanding of concepts such as innovation and social responsibility; employees who know about continuous innovation did not express fear of failure, unlike those who do not know about CSR and innovation (Molina, 2011).

According to Pedroza (2016), corporate sustainability is a tool to provide timely information to the market and investors, which will allow to know if the operations or growth are sustainable in the medium and long term. With this, it can be assumed that sustainability could be one of theorganizations' responses to the environmental and social challenges that act as opportunities to increase revenues or threats that affect the operation of the company.

The real economic reason to defend sustainable tourism is that, if you do not fight for sustainability, in the end you can lose the entire industry. The tourist bet, in the future, will be increasingly difficult, and those destinations that are better preserved and that can offer tourists a more environmentally, socially and economically responsible vacation, will be chosen by tourists of the future(Carbó, 2013, p. 43).

\section{The road to responsible tourism}

It is clear that sustainability is part of the operational reality in different business contexts, and tourism is no exception. Particularly, the hotel industry is a sensitive subsector to these issues if a functional risk map is made and triple accountability (social, economic and environmental) is taken into account.

In a strict sense, Sustainable Hospitality could be defined as "Accommodation that, regardless of its classification, category, location and / or type of operation, is based on its design and management of economicstrategic, environmental, social and cultural principles..." (Sustainable Hotels, 2011). That is, to ensure that a hotel lasts over time it is necessary to ensure the alignment of corporate strategies to corporate social responsibility in the basic factors: environmental, social and economic.

According to the Rainforest Alliance (s.f), there are some general guidelines and benefits derived from the application of the concept of sustainability (Table 2). 
Table 2. Guidelines and Benefits of the Application of the Concept of Sustainability

\begin{tabular}{|l|l|}
\hline \multicolumn{1}{|c|}{ Guidelines } & \multicolumn{1}{|c|}{ Benefits } \\
\hline $\begin{array}{l}\mathrm{N}^{\circ} \text { renewable resource should be used at a higher rate than is } \\
\text { required to replenish it. }\end{array}$ & $\begin{array}{l}\text { The higher the landscape quality, in which the hotel is, the } \\
\text { higher the quality of tourists or guests of this hotel (Carbó, } \\
2013) \\
\mathrm{N}^{\circ} \text { contaminating product should be produced at a higher } \\
\text { rate than can be recycled, neutralized or absorbed by the } \\
\text { environment. }\end{array}$ \\
$\begin{array}{l}\mathrm{N}^{\circ} \text { non-renewable resource should be used faster than } \\
\text { necessary to replace it with a renewable resource used in a } \\
\text { sustainable way. }\end{array}$ & $\begin{array}{l}\text { Cost reduction } \\
\text { Employee commitment: “Employee morale and competitive advantages by using the } \\
\text { are linked to productivity, recruitment and retention." } \\
\text { License to operate } \\
\text { Greater innovation (Friedman, 2017) }\end{array}$ \\
\hline \multicolumn{2}{|c|}{ Source: Author's own elaboration based on Carbó (2013) and Friedman (2017). } \\
\hline
\end{tabular}

\begin{tabular}{|c|c|c|}
\hline Economic & Environmental & Social \\
\hline Cost of employees training & CO2 emissions & Employees number \\
\hline Board of directors size & Water use & Employees rotation \\
\hline $\begin{array}{c}\text { Duration of the board of the directors } \\
\text { in years }\end{array}$ & Water waste treatment & Average age of employees \\
\hline Degree of influence of board members. & Amount of waste produced & Number of employees \\
\hline $\begin{array}{c}\text { Income of the company Vs. GDP of } \\
\text { Colombia. }\end{array}$ & $\begin{array}{c}\text { Amount of energy consumed and energy } \\
\text { efficiency policy }\end{array}$ & Women in the administration \\
\hline ISO 9001 & Paper consumption & Number of disabled on the payroll \\
\hline Investment / Environmental liabilities & ISO 140001 & Management of the social supply chain \\
\hline $\begin{array}{l}\text { Expenses/Income (environmental } \\
\text { management) }\end{array}$ & Waste reduction policies & Community spending \\
\hline Investment in sustainable operations & Water use and biodiversity policies & $\begin{array}{l}\text { Infrastructure adaptation for people } \\
\text { with disabilities }\end{array}$ \\
\hline Investment in the social supply chain & Green Building Policy & The Code \\
\hline \multicolumn{3}{|c|}{ Source: Bloomberg, 2017.} \\
\hline
\end{tabular}

On the other hand, a more strategic vision of sustainability results in the need for a series of standards for sustainable practices and / or sector certifications that guarantee a certain level of commitment to social responsibility and particularly the contemporary vision of sustainability. For example, the following table presents a series of variables regarding sustainability that should be a minimum in terms of the application of responsible practices on the part of the hotels (Table 3). 


\begin{tabular}{|c|c|}
\hline & Table 4. Quality and CSR Certifications for Hotels \\
\hline Certification & Features \\
\hline Trip Advisor excellence & $\begin{array}{l}\text { It is aimed at certain accommodations, attractions and restaurants that constantly demonstrate } \\
\text { a commitment to hospitality excellence. } \\
\text { Use an algorithm of your property to determine the winners of this certificate that is based on } \\
\text { the quantity and quality of opinions of the different places, the time of the establishment and its } \\
\text { classification of popularity, these factors are observed for } 12 \text { months, so that you be granted. }\end{array}$ \\
\hline The Code & $\begin{array}{l}\text { It is a Code of Conduct created with the initiative of providing protection to children and young } \\
\text { minors, as opposed to commercial sexual exploitation that results from tourism and travel. } \\
\text { Among the requisites required are to establish business ethical policies against sexual exploitation } \\
\text { of minors, establish clauses with direct and indirect employees of the organization that express } \\
\text { their disapproval and rejection of sexual exploitation of minors, instruct and inform to tourists and } \\
\text { interest groups on the policies established against sexual exploitation in the organization }\end{array}$ \\
\hline $\begin{array}{l}\text { NTS-TS- } 002 \text { Cer-tification } \\
\text { of quali-ty and tourism } \\
\text { sustainability }\end{array}$ & $\begin{array}{l}\text { It was created with the ideal of being a comparative tool through which the community can } \\
\text { identify which products and services have better environmental performance, encourage products } \\
\text { and services to acquire this label for less environmental damage, promote and facilitate the entry } \\
\text { into the market of those products and services that are friendly to the environment }\end{array}$ \\
\hline $\begin{array}{l}\text { NTC } 5133 \text { Colombian } \\
\text { environmental seal. }\end{array}$ & $\begin{array}{l}\text { The Colombian Environmental Seal is an ecological certification or label that can carry a } \\
\text { certain good or service as long as it meets the established requirements, it is voluntary and it is } \\
\text { also granted by an inspection body previously certified by the ONAC (National Organization of } \\
\text { Colombian Accreditation }\end{array}$ \\
\hline $\begin{array}{c}\text { ISO } 140001 \\
\text { Environmental } \\
\text { management system }\end{array}$ & $\begin{array}{l}\text { It is intended to support the application of an environmental management plan in any public } \\
\text { or private sector organization. It requires the company to create an environmental management } \\
\text { plan that includes: environmental objectives and goals, policies and procedures to achieve those } \\
\text { goals, defined responsibilities, staff training activities, documentation and a system to control any } \\
\text { changes and progress made. }\end{array}$ \\
\hline $\begin{array}{l}\text { ISO } 9001 . \\
\text { management }\end{array}$ & $\begin{array}{l}\text { This standard seeks to adopt a process-based approach to increase customer satisfaction by } \\
\text { meeting their requirements. The continuous improvement and supervision of its processes is } \\
\text { sought so that these are carried out and configured in such a way that the operation of the company } \\
\text { is more efficient and generates greater satisfaction for its customers. }\end{array}$ \\
\hline & Source: Author's own elaboration Based on Rincon (2002). \\
\hline
\end{tabular}

Below are the limitations, requirements and benefits of the certifications that hotels can acquire, related to social responsibility and quality, in order to identify what specific characteristics are hotels that have certain certifications and know what each one refers to in the cases that we will relate later (Table 4)

On the other hand, below, Graph 1 is presented, which identifies a comparison of the implementation of the certifications and the amount in which they have been granted.

According to these statistical data, it would seem that the bad image that the hotel subsector can show, would be given, in part, by the fact that they lack much to improve and implement in the environmental field, despite the fact that this is the main area working hotels internationally. 


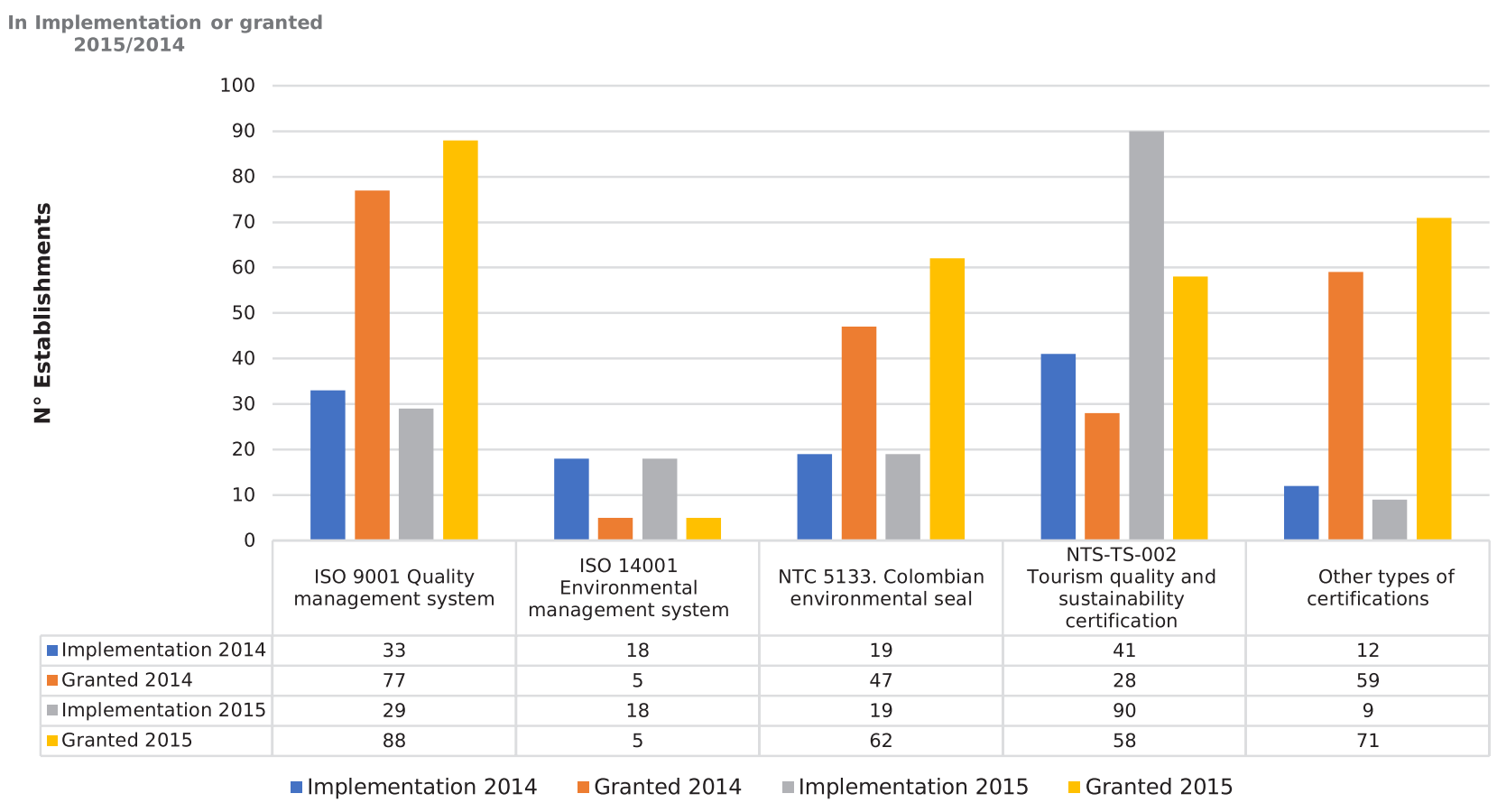

Source: Author own elaboration, based on DANE, 2015.

\section{Conclusions and discussion}

From the documentary analysis carried out in this article, some significant conclusions could be reached. In the first instance, it must be understood that tourism is "a social, cultural and economic phenomenon related to the movement of people to places outside their usual place of residence for personal or business / professional reasons" (World Organization of Tourism, 2014). The tourism sector is formed by several subsectors, such as accommodation, travel agencies and tour operators, transport and rental of vehicles, among others (Exceltur, 2015; Castillo, 2016, p. 33).

Therefore, social responsibility is closely related to the sustainable development potential of the hotel subsector, whether in its economic, social or environmental component. It becomes clear that these types of organizations have a series of large-scale impacts due to the nature of their operations, in terms of job creation (impacting the labor supply of local communities), types of contracts, anti-discrimination policies, operational efficiencies that reduce the ecological footprint (carbon, water or general environmental), fight against exploitation and sexual tourism among many other aspects. Thus, the CSR is configured in a value creation tool for the hotel subsector.

In the second instance, among the problematic findings of the studies carried out in relation to CSR and the hotel sector, there is a wide confusion, among hotel managers, about the concepts of Corporate Social Responsibility and sustainable tourism (Ayuso, 2006).

On the other hand, it has been seen that at the international level the emphasis of social responsibility inside the hotels is raised in the environmental component and much about savings at the water level and inputs from consumer psychology strategies, as a feeling of fault (the case of the reuse of towels in the rooms) In this sense, it becomes clear that global hotels, especially high-end hotels tend to take more responsibility and 
are more actively involved in CSR compared to accommodation properties of lower price (Gard McGehee, Wattanakamolchai, Perdue, and Onat Calvert, 2009). However, it seems to be a reality that the impact generated in the local community or directly on its employees does not enjoy greater attention in the hotel sector (Fernández and Cuadrado, 2011). It is for this reason that hotels have been inclined to be friendly to the environment and to carry out practices that are not aggressive with the environment, seeking to be "eco-efficient", which according to the World Business Council for Sustainable Development (WBCSD) is defined as: Provide goods and services at a competitive price, satisfying human needs and quality of life, while progressively reducing the environmental impact and intensity of the use of resources throughout the life cycle, to a level compatible with the estimated capacity that the Planet can support (Estévez, 2015).

However, from the documentary review it is also inferred that the social responsibility applied in the hotel subsector positively affects customer loyalty, so that variables such as image and reputation are fundamental in the sustainability of the industry, particularly when National and regional level is making a "millionaire" bet in the tourism sector.

The challenge, then, implies that progress is needed from sustainable tourism to responsible tourism, since there is an implicit difference. According to Goodwin (2016) responsible tourism places the emphasis on what people and groups of people do to cope with those sustainability issues that leave or derive in particular places, attacking local priorities, transparently reporting what is being done to address those priorities. Therefore, there is a continuum that must be followed from the reality that occurs in most of the tourist destinations where the hotels operate to the must be where the tourism responsible for a specific destination would be located.

The gap is still relevant and that necessarily implies improving knowledge, skills, performance, impacts on the business management of the hotels, they would be two sides of a constantly evolving continuum in which the emphasis, on the one hand, is on the tasks of the people and, on the other, in the pillars of sustainability that are not necessarily the same for all types of destinations.

Additionally, there are other challenges to work under a sustainability perspective.

Although there is greater emphasis on environmental practices, it is necessary to investigate:

- How CSR impacts pre-purchase decisions in the subsector.

- Hotel investment plans with an impact on the environment.

- Sensitization and sensitivity analysis on the different sustainability practices (Table 1).

- Relationship with more efficient costs in operational management.

- Reduction of impacts.

The relevance of the impact caused in local communities from the social does not seem to be minimal or nonexistent in some cases. The challenge revolves around:

- Have the ability to generate the social license to operate.

- Recruitment and retention of employees contributing to the local community.

- Recognition for local hiring practices, fight against discrimination, better working conditions and donations and creation of foundations.

- Key communication to be perceived as good corporate citizens.

- Transversal issues such as the fight against sexual exploitation.

\section{Conflict of interest}

The authors declare no conflict of interest.

\section{Source of Financing}

This research is sponsored by Universidad del Norte, Barranquilla, Colombia. 


\section{References}

Abello, A., \& Sendra Vellvé, J. (2007). RSC y empresa turística. Evaluación de los parámetros de Responsabilidad Social Corporativa. Desarrollo de aplicación piloto en la Costa Dorada. Tarragona, España: Comisión de Medio Ambiente de Cambra.

Assaf, G., Josiassen, A., Jin Sun, Ahn., \& Mattila. A. (2017). Advertising spending, firm performance, and the moderating impact of CSR. Tourism Economics, 23(7), 1-12. https:// doi.org/10.1177/1354816617704739

Ayuso, S. (2006). Adoption of voluntary environmental tools of sustainable tourism: analyzing the experience of Spanish hotels. Corporate Social Responsibility and Environmental Management, 13(4), 207-220. https://doi.org/10.1002/csr.103

Bigné, J., Font, X., \& Andreu, M. L. (2000). Marketing de destinos turisticos. Madrid, España: Editorial Esic.

Bohdanowicz, P., \& Zientara, P. (2008). Hotel Companies' Contribution to Improving the Quality of Life of Local Communities and the Well-being of their Employees. Tourism and Hospitality Research, 9(2), 147-158. https://doi. org/10.1057/thr.2008.46

Carbó, D. (2013). Impacto ambiental del sector hotelero en clima cálido-húmedo. Evaluación y propuestas de mejora. Barcelona, España: Universidad Politécnica de Cataluña.

Carroll, A. B. (1999). Corporate social responsibility: evolution of definitional construct. Business \& Society, 38(3), 268-295. https://doi.org/10.1177/000765039903800303

Castillo García, I. (2016). La comunicación de la RSE en el sector hotelero español. España, Madrid: Universidad Complutense de Madrid.

Del Río, J., Cardona, D., Pérez, I. (2012). Desarrollo de actividades de emprendimiento con innovación y responsabilidad social en los hoteles de la ciudad de Cartagena de Indias. Saber, Ciencia y Libertad, 7(2), 113-124. https://doi. org/10.18041/2382-3240/saber.2012v7n2.1804

Dimitrova, D., \& Li, N. (2016). Corporate Social Responsibility in Tourism: How can a CSR certificate enhance the competitive advantage of tourism SMEs in Denmark - case study of Travelife Certification. Retrieved from http:/l projekter.aau.dk/projekter/files/239521829/ MASTER OF THESIS Denitsa Dimitrova Ning_Li_.pdf
Ejarque, J. (2005). Destinos turísticos de éxito. Diseño, creación, gestión y marketing. Madrid, España: Editorial Pirámide.

Estévez, R. (2015). ¿En qué consiste la ecoeficiencia? Recuperado de https://www. ecointeligencia.com/2015/11/ecoeficiencia/

Exceltur. (2015). Perspectivas turísticas Valoración empresarial del verano de 2015 y perspectivas para el cuarto Informe Perspectivas. Recuperado de http://www.exceltur.org/wp-content/ uploads/2015/10/Informe-Perspectivas-N54IITR-de-2015-y-perpectivas-para-el-cierrede-2015.pdf

Fernández, G. R. (2009). Responsabilidad social corporativa: una nueva cultura empresarial. Madrid, España: Madrid Club Universitario.

Fernández Alles, M. T., \& Cuadrado Marqués, R. (2011). La responsabilidad social empresarial en el sector hotelero. Revisión de 133 la literatura científica, Cuadernos de Turismo, (28), 47-57. Recuperado de https://revistas.um.es/turismo/ article/view/147181

Flores-Ruiz, D., Bino-Raya, R., \& BarrosoGonzález, M. (2016). Responsabilidad social en el sector hotelero. Análisis de caso en Córdoba (Argentina). Revista de Globalización,Competitividad y Gobernabilidad, 10(3), 116-135. Recuperado de https://www. redalyc.org/articulo.oa? $\mathrm{id}=511854477002$

Gao, Y., \& Mattila, A. S. (2014). Improving consumer satisfaction in green hotels: the roles of perceived warmth, perceived competence, and CSR motive. International Journal Hospitality Management, 42, 20-31. https://doi. org/10.1016/j.jihm.2014.06.003

García-Rodríguez, F. J., \& Armas-Cruz, Y. del M. (2007). Relation between social-environmental responsibility and performance in hotel firms. International Journal of Hospitality Management, 26(4), 824-839. http://dx.doi.org/10.1016/j. ijhm.2006.08.003

González-Morales, O., Álvarez-González, J. A., Sanfiel-Fumero, M. Á., \& Armas-Cruz, Y. (2016). Governance, corporate social responsibility and cooperation in sustainable tourist destinations: the case of the island of Fuerteventura. Island Studies Journal, 11(2), 561-584. Retrieved from https://www.islandstudies.ca/sites/default/ files/ISJ-11-2-MS314-Gonzales-Morales_0.pdf

Goodwin, H. (2016). Responsible tourism: using tourism for sustainable development ( $2^{\text {nd }}$ edi.). Oxford, UK: Goodfellow publishers. 
Hoteles Sostenibles. (2011). ¿Qué es un hotel sostenible? Recuperado de $\quad$ http://hotelessostenibles.com/ que-es-un-hotel-sostenible/

Jaume, C. (2015) ¿Es su hotel socialmente responsable? Recuperado de http://www. winhotelsolution.com/es/blog/software-hotel/ es-tu-hotel-socialmente-responsable/

Jiménez Martínez, A de J. (2008). Las cadenas hoteleras en el mundo y evolución de su operación en México al inicio del siglo XXI. INNOVAR, 18(32), 167-194. DOI: 10.15446/ innovar

Kabir, M. (2011). Corporate social responsibility by Swaziland hotel industry. Procedia - Social and Behavioral Sciences, 25, 73-79. https://doi. org/10.1016/j.sbspro.2011.10.529

Kang, E., \& Atkinson, L. (2016). Prosocial Outcomes of Hotel's CSR-Perceived Motives. Social Marketing Quarterly, 22(4), 307-324. https://doi.org/10.1177/1524500416642440

Kim, Y., Kim, M., \& Mattila, A. S. (2016). Corporate Social Responsibility and Equity Holder Risk in the Hospitality Industry. Cornell Hospitality Quarterly, 58(1), 81-93. https://doi. org/10.1177/1938965516649052

Kirk, D. (1995). Environmental Management in hotels. International Journal of Contemporary Hospitality Management, 7(6), 3-8. https://doi. org/10.1108/09596119510095325

Martínez P., \& Rodríguez del Bosque, I. (2013). CSR and customer loyalty: the roles of trust, customer identification with the company and satisfaction. International Journal Hospitality Management, 35, 89-99. https://doi.org/10.1016/j. ijhm.2013.05.009

Martínez P., Perez, A., \& Rodríguez del Bosque, I. (2013). Measuring Corporate Social Responsibility in Tourism: Development and Validation of an Efficient Measurement Scale in the Hospitality Industry. Journal of Travel \& Tourism Marketing, 30, 365-385. https://doi.org L10.1080/10548408.2013.784154

Martos Molina, M. (2011). La responsabilidad social corporativa en la gestión hotelera. Turismo y Sociedad, 12, 169-184. Recuperado de http://revistas.uexternado.edu.co/index.php/ tursoc/article/view/3122/3504

Martos, M., y Pulido, J. I. (2011). Retos para la gestión turística de los destinos urbanos culturales. Mallorca, España: Servicio de Publicaciones de la Universidad de Islas Balares.
Melo, T., Cox Moura-Leite, R., \& Carlton Padgett, R. (2012). Conceptualization of corporate social responsibility by the luxury hotels in Natal/ RN, Brazil. Caderno Virtual de Turismo, 12(2), 152-166.

Gard McGehee, N., Wattanakamolchai, S., Perdue, R. R., \& Onat Calvert, E. (2009). Corporate Social Responsibility Within the U.S. Lodging Industry: an Exploratory Study. Journal of Hospitality \& Tourism Research, 33(3), 417-437. https://doi.org/10.1177/1096348009338532

Ministerio de comercio industria y turismo. (2014). Requisitos de sostenibilidad establecimientos de alojamiento y hospedaje. Recuperado de http:// rntneiva.confecamaras.co/ckfinder/userfiles/ files/NTS\%20\%E2\%80\%93\%20TS\%20002 \%20 Establecimientos\%20de\%20alojamiento\% $\overline{2} 0$ y\%20hospedaje\%20(EAH) \%20Requisitos $\% 20$ de\%20sostenibilidad \%202014.pdf

Molina, M. M. (2011). La responsabilidad social corporativa en la gestión hotelera. Recuperado de http://revistas.uexternado.edu.co/index.php/ tursoc/article/view/3122/3504

Ocampo, C. (2015). Responsabilidad social empresarial de los hoteles cinco estrellas del centro histórico: una manera de contribuir con la sostenibilidad del destino turístico de Cartagena de Indias. Métodos, 15, 96-108. http:// openjournalsys.colmayorbolivar.edu.co/index. php/Methodos/article/view/17/35

Organización Mundial del Turismo. (2014). Entender el turismo: Glosario Básico. Recuperado de http://media.unwto.org/es/ content/entender-el-turismo-glosario-basico

Pedroza, J. V. (2016). ¿Qué es la Sostenibilidad Corporativa? Recuperado de http://gestion.pe/gestion-tv/ que-sostenibilidad-corporativa-2153785

Peña, D., Guevara, A., y Fraiz Brea, J. 2016. $\mathrm{La}$ investigación de la responsabilidad social empresarial en el sector hotelero. Análisis y revisión de la literatura científica. Turismo y Sociedad, 18, 137-158. https://doi. org/10.18601/01207555.n18.08

Pérez, A., and Rodríguez del Bosque, I. (2015). Corporate social responsibility and customer loyalty: exploring the role of identification, satisfaction and type of company", Journal of Services Marketing, 29(1), 15-25. https://doi. org/10.1108/JSM-10-2013-0272

Porter, M. E., \& Kramer, M. E. (2006). Strategy and Society: The Link between Competitive Advantage and Corporate Social Responsibility. 
Harvard Business Review, 78-92). Retrieved from https://sharedvalue.org/sites/default/files/ resource-files/Strategy and Society.pdf

Rainforest-alliance. (s.f.). Buenas Prácticas para turismo sostenible. Recuperado de https:// www.rainforest-alliance.org/business/tourism/ documents/tourism_practices_guide_spanish. pdf

Raufflet, E. (2012). Responsabilidad Social Empresarial. Ciudad de México, México: Editorial Pearson.

Romo Mendoza, N. (2017). El Sector Hotelero Impulsado por la Inversión y el Turismo. Recuperado de https://www.elheraldo.co/masnegocios/el-sector-hotelero-impulsado-por-lainversion-y-el-turismo-363095

Torres Castillo, C., \& Idrovo Carlier, S. (2013, Julio). Responsabilidad Social Empresarial en el Sector Hotelero Colombiano. Portafolio. Recuperado de http://www.portafolio.co/ opinion/redaccion-portafolio/responsabilidadsocial-sector-hotelero-colombiano-83850

Torugsa, N., O’Donohue, W., \& Hecker, R. (2013). Proactive CSR: An empirical analysis of the role of its economic, social, and environmental dimensions on the association between capabilities and performance. Journal of Business Ethics, 115(2), 383-402. https://www. jstor.org/stable/42001990
Vaca, R. (2013). Responsabilidad social corporativa en las cadenas hoteleras españolas: factores determinantes de su nivel de desarrollo y consecuencias (Tesis doctoral). Universidad de Huelva, Huelva, España. Recuperado de http://rabida.uhu.es/dspace/bitstream/ handle/10272/7260/Responsabilidad social corporativa.pdf?sequence $=2$

Valls, J. F. (2004). Gestión de destinos turísticos sostenibles. Barcelona, España: Editorial Gestión 2000.

Vega Mora, L. (2013). Dimensión Ambiental, Desarrollo Sostenible y Sostenibilidad Ambiental del Desarrollo. Recuperado de http://www.laccei.org/LACCEI2013-Cancun/ RefereedPapers/RP256.pdf

Vo, L., Delchet-Coche, K., \& Akeb, H. (2015). Motives Behind the Integration of CSR Into Business Strategy: A Comparative Study in French SMEs. Journal of Applied Business Research, 31(5), 1975-1986.

Yixiu, A., \& Tun.Min, J. (2017) The impact of green experience on customer satisfaction: evidence from TripAdvisor. International Journal of Contemporary Hospitality Management, 29(5), 1340-136. https://www.emerald.com/insight/ content/doi/10.1108/IJCHM-07-2015-0371/full/ html

¿How to quote this article?

Mejía Reátiga, C., \& Ortíz Torres, M. (2020). Reflections on Responsible Tourism in the Framework of Social Responsibility. Cuadernos de Administración, 36(66), 148-160. https://doi.org/10.25100/cdea.v36i66.7196 